\title{
Three War Veterans Who Don't Tell War Stories
}

\section{Kate McLoughlin}

This is an essay about three literary war veterans, created by William Wordsworth, Rebecca West and Virginia Woolf in 1798, 1918 and 1925. All three of these veterans fight in modern warfare; that is, warfare that has a global reach, involves mass participation, features industrialised weapons technology and (as will be explained) depends for its successful conduct on management of an unusually high degree of chance. Participating as a combatant in such warfare is taken by Wordsworth, West and Woolf, all civilians themselves, to be an experience that is incomprehensible, unassimilable and (hence) unshareable. Their veterans are all notable for not talking about what they have been through. Words having failed, all that is left is the body which has literally gone through the wars, stared at in consternation rather than with understanding. Unknowing (a term I take from Philip Weinstein), ${ }^{1}$ they are also unknowable. But these literary veterans do more than signify the senselessness of the wars in which they have participated. In my reading, they are impedimenta in the project of modernity-modernity understood, after Theodor Adorno and Max Horkheimer, ${ }^{2}$ as the Enlightenment process of replacing myth with scientific method. The texts in which these veterans appear are William Wordsworth’s 'The Discharged Soldier', Rebecca West's The Return of the Soldier and Virginia Woolf's Mrs Dalloway. But before discussing them, I shall devote some time to the connections between veterancy, experience and storytelling, with reference to Walter Benjamin’s 1936 essay ‘The Storyteller’ (Der Erzähler).

\footnotetext{
${ }^{1}$ Philip Weinstein, Unknowing: The Work of Modernist Fiction (Ithaca: Cornell University Press, 2005).

2 Theodor Adorno and Max Horkheimer, Dialectic of Enlightenment, trans. John Cumming (London: Verso, 1979).
} 


\section{'The Storyteller'}

In this essay Benjamin identifies two kinds of storyteller: the person who has come from afar and the person who stays at home. ${ }^{3}$ The former tells stories of distant places, the latter of distant times. The home-stayer is embodied in 'the resident tiller of the soil', the traveller in the 'trading seaman'. ${ }^{4}$ According to Benjamin, the storyteller 'takes what he tells from experience', which can either be his own or that reported by others. ${ }^{5}$ In turn, he makes it the experience of those who are listening to his tale. ${ }^{6}$ The 'experience' that Benjamin has in mind is expressed by the German word Erfahrung, which is distinct from Erlebnis, also translated as 'experience' in English. Erlebnis, from the verb leben (to live), denotes 'immediate' or 'isolated' experience, as Benjamin elsewhere puts it. ${ }^{7}$ This is experience in the raw, unreflected upon; it is immediate, often shocking experience, with a high impact on the senses. Erfahrung, from the verb fahren (to travel), signifies cumulative experience 'that accompanies one to the far reaches of time' ${ }^{8}$ Erfahrung, in a tradition that can be traced back to Plato via Kant, Hume, Locke and Augustine, encompasses both outer sense impressions and cognitive judgements about them; in Martin Jay's words, 'a more temporally elongated notion of experience based on a learning process, an integration of discrete moments of experience into a narrative whole or an adventure'. ${ }^{9}$

\footnotetext{
${ }^{3}$ Walter Benjamin, 'The Storyteller: Observations on the Works of Nikolai Leskov' [1936], Selected Writings. Volume 3: 1935-38, ed. Howard Eiland and Michael W. Jennings, trans. Harry Zohn (Cambridge: The Belknap Press of Harvard University Press, 2002), 143-66: p. 144.

${ }^{4}$ Ibid., p. 144

${ }^{5}$ Ibid., p. 146.

${ }^{6}$ Ibid., p. 146.

${ }^{7}$ Walter Benjamin, 'Some Motifs in Baudelaire' [1939], Selected Writings. Volume 4: 1938-40, ed. Howard Eiland and Michael W. Jennings, trans. Harry Zohn (Cambridge: The Belknap Press of Harvard University Press, 2003), 313-55: pp. 333, 317.

${ }^{8}$ Ibid., p. 331.

${ }^{9}$ Martin Jay, Songs of Experience: Modern American and European Variations on a Universal Theme (Berkeley: University of California Press, 2006), p. 11.
} 
Veterancy encapsulates this latter kind of experience. The word 'veteran' comes from the Latin vetus, meaning 'old', which itself relates to the Proto-IndoEuropean *wetos-, meaning 'year'. ${ }^{10}$ Since 1509 , the word has connoted a person with long military service ${ }^{11}$ (the primary sense in which we understand it today), but etymologically speaking, it is possible to become a veteran simply by growing older-you're veterating as you're reading this. Veterancy, that is, is both a condition of, and an apt figure for, Erfahrung. The most natural genre for the transmission of Erfahrung, as Benjamin points out, is the story. Benjamin paints a picture of experience passed on in a storytelling chain: a handing-round, rather than a handingdown, of wisdom consisting of knowledge once personally acquired and subsequently reflected upon. And, in a tradition that reaches from Odysseus to Uncle Albert in the BBC sitcom Only Fools and Horses, veterans are notorious storytellers.

But in 'The Storyteller' Benjamin warns that storytelling as the passing on of Erfahrung has been attenuated by certain of the developments of modernity. 'The art of storytelling is coming to an end,' he warns. 'It is as if a capability that seemed inalienable to us, the securest among our possessions, has been taken from us: the ability to exchange experiences.' ${ }^{12}$ The factors in this denudation are industrialisation, the fragmentation of traditional communities, bourgeois individualism and the rise of mass media: in other words, the arrival of the age of mechanical reproduction. With this age has come the ascendancy of information and immediate explanation over the kind of knowledge purveyed by storytelling, ${ }^{13}$ an ascendancy epitomized in Benjamin's assessment of the poetics of the novel. These factors identified, Benjamin then comes, in the most famous passage in 'The

\footnotetext{
10 'Veteran, n. and adj.’, The Oxford English Dictionary (OED Online), accessed 19 February 2016.

${ }^{11}$ Ibid.

12 Benjamin, 'The Storyteller', p. 143.

13 Ibid., p. 147.
} 
Storyteller', to the prime cause of the demise of storytelling as an event of the early twentieth century:

Beginning with the First World War, a process became apparent which continues to this day. Wasn't it noticeable at the end of the war that men who returned from the battlefield had grown silent-not richer but poorer in communicable experience? What poured out in the flood of war books ten years later was anything but experience that can be shared orally. ${ }^{14}$

'Men returned from the battlefield grown silent-not richer but poorer in communicable experience.' $^{15}$ The line can be read as a statement about traumainduced aphasia: indeed, Cathy Caruth claims that the soldier is 'the central and recurring image of trauma in [the twentieth] century'. ${ }^{16}$ But for the purposes of this essay I want to consider its epistemological significance. Benjamin was not suggesting that the war was indescribable: the 'flood of war books' that poured out ten years later could and did describe what was horrific and shocking—Erlebnis, that is. ${ }^{17}$ Rather, it could not be made sense of, was resistant to comprehension and assimilation and, therefore, transmission, because it is impossible to learn and teach from experience if you don't understand that experience in the first place. In Benjamin’s poignant words:

A generation that had gone to school on horse-drawn streetcars now stood under the open sky in a landscape where nothing remained unchanged but the

\footnotetext{
${ }^{14}$ Ibid., p. 143-4.

${ }^{15}$ The original phrase is 'nicht reicher-ärmer an mitteilbarer Erfahrung' (Walter Benjamin, 'Der Erzähler', Gesammelte Schriften, ed. Hermann Schweppenhäuser and Rolf Tiedemann (Frankfurt am Main: Suhrkamp, 1972-), II.2.438-65: p. 439.

${ }^{16}$ Cathy Caruth, Unclaimed Experience: Trauma, Narrative and History (Baltimore: The Johns Hopkins University Press, 1996), p. 11.

${ }^{17}$ Benjamin's original German is 'alles andere als Erfahrung, die von Mund zu Mund geht' (Benjamin, 'Der Erzähler', p. 439): literally 'completely different from experience [Erfahrung] that goes from mouth to mouth'. Ernst Jünger's Der Kampf als inneres Erlebnis (1922) ('The War as Inner Experience') and his book of war photographs, Der Antlitz des Weltkrieges: Fronterlebnisse deutscher Soldaten (1930) (The Face of the Great War: Front Experiences of German Soldiers'), record instances of Erlebnis.
} 
clouds, and beneath those clouds, in a force field of destructive torrents and explosions, was the tiny, fragile human body. ${ }^{18}$

No story can be told when the storyteller has nothing in his past experience with which to compare his present experience. All that remains-when it escapes pulverization—is the physically veterated body. It is an ironic body—ironic because its ostensible message is at odds with its actual message. For Benjamin insisted on the corporeal nature of storytelling: 'traces' of the storyteller 'cling' to a story in the same way that 'the handprints of the potter'-hands again — 'cling' to a 'clay vessel'. ${ }^{19}$ But the injured / incomplete body produced by mechanized mass warfare is the sign of having no mature wisdom to hand on. The war-wearied yet uncommunicative veteran signifies the demise of storytelling. And this, I suggest, is the figure we encounter in Wordsworth's 'The Discharged Soldier', West's The Return of the Soldier and Woolf's Mrs Dalloway.

\section{William Wordsworth, ‘The Discharged Soldier’ (1798)}

We meet our first literary war veteran at the side of a road in the Lake District, in William Wordsworth's 170-line poem 'The Discharged Soldier', written in 1798. The poem opens with the speaker taking a stroll in the moonlight. The early lines of the poem establish an intimate connection between 'animal delight' and 'selfpossession' on the one hand and the rhythm of walking on the other (ll. 35-7). ${ }^{20}$ Restored 'in every pause / And every gentle movement of my frame' (ll. 34-5), the speaker is visited by 'beauteous pictures' and 'harmonious imagery' (ll. 28, 29).

\footnotetext{
${ }^{18}$ Benjamin, 'The Storyteller', p. 144.

19 Ibid., p. 148.

${ }^{20}$ All quotations from Wordsworth's works are from The Cornell Wordsworth (1975-2007), gen. ed. Stephen Maxfield Parrish, 21 vols. Line numbers are given in the text.
} 
Walking, that is, is conducive to, and a figure for, personal well-being, mental alertness, creativity and expression.

But all these good things are interrupted when the speaker catches sight of something so extraordinary that his immediate impulse is to dart behind a tree. What he sees is an 'uncouth shape' (1. 38), a figure wholly outside his experience. ${ }^{21}$ This 'uncouth shape' is a war veteran, a soldier who 'to the tropic isles had gone' (l. 99)_ a detail that tells us that he has fought in the French Revolutionary Wars in the West Indies that stretched from 1792 to 1802 . Unlike the speaker, the veteran is not walking along the road. But it is not just that he is not walking. One of the most striking things about him is his extremely long legs—legs so long, indeed, that they make the viewer forget about the rest of his body (ll. 46-7):

His legs were long.

So long and shapeless that I looked at them

Forgetful of the body they sustained. (1l. 46-7)

The immobility of these extraordinarily long legs means that the Soldier's notwalking is not just one of a range of activities he happens not to be performing, but a salient fact. He is preternaturally still: 'fixed to his place', maintaining a 'fearful steadiness'; even his shadow 'moved not' (ll. 76, 71, 72). In a historical context in which veterans had a limited time-period within which to return to their native parishes for pensions and relief, the riskiness of this halt emphasises its strangeness.

If walking is about expressiveness, motionlessness is about its opposite-and here it might be remembered that one of Benjamin's avatars for the storyteller is the wayfarer. The majority of the Soldier's utterances are pre-verbal noises: 'murmuring sounds', ‘a murmuring voice of dead complaint’, ‘[a] groan scarce audible’ (ll. 70, 78,

\footnotetext{
21 'Uncouth, adj. and n.,' 2. 'With which one is not acquainted or familiar; unfamiliar, unaccustomed, strange’, Oxford English Dictionary, 2nd ed. online, accessed 5 May 2016.
} 
79). Non-functioning legs / non-functional words: the Soldier who doesn’t walk barely talks. But, as everybody knows, war veterans tell war stories. And so, the speaker prompts him to recount some. The reply comes 'neither slow nor eager' (l. 95). Not satisfied, the speaker resumes his probing in line 125 and again in line 135 ('I did not fail / To question him of what he had endured / From war, and battle, and the pestilence'). In each instance, the Soldier's responses are distinctly underwhelming. When, at last, he does speak directly, the effect is extremely muted. His volume is 'quiet', his air 'stately' and 'mild', his demeanour 'calm', his tone one of 'weakness and indifference' (ll. 96, 97, 138, 142). His own recital leaves him 'unmoved' (1. 95). Derring-do, blood-and-gore, conspicuous bravery, thrilling escape: all the matter that might be expected in a war story is wholly absent. Instead, interchange actually grinds to a halt. The speaker gives up trying to make conversation and 'discourse [...] cease[s]' (1. 146). Rather than concluding, the poem simply ends_-in a strangely subdued parting with no summative comment.

Physically, Wordsworth’s Soldier shouts ‘veterancy’. Being ‘clad in military garb’ defines him obviously enough as a former member of the army, but it is the additional information that the garb is 'faded' (ll. 53-5) which encapsulates the notion of having undergone experience over time. Veterancy is also inscribed on his body, in his 'wasted' visage, his 'sunken' cheeks, his 'ghastly' mouth, his 'meagre stiffness' (ll. 49, 50, 51, 44). But this veteran is strangely detached from his own veterancy:

solemn and sublime

He might have seemed, but that in all he said

There was a strange half-absence, and a tone

Of weakness and indifference, as of one

Remembering the importance of his theme 
But feeling it no longer. (ll. 139-44)

The Soldier is dissociated from his own experiences, unable to 'feel' what has happened to him, a spectator of, rather than a participant in, his past history. It is not even the case that his experiences have been such as to elicit awe and wonder, a state of affairs which might have placed them in the zone of the 'sublime'. They simply mean nothing to him. If a veteran is one who, by definition, has matured through time, this veteran has become older but not wiser. His experiences have left their mark on him corporeally but he is unable to assimilate them, let alone to pass them on, whether in the form of a tale or otherwise, to this or any other interlocutor.

This absence of communicative exchange in 'The Discharged Soldier' has been read from (often overlapping) ideological, philosophical and psychological perspectives. Critics have charged Wordsworth with failing to grasp the social and political implications of the rural poverty in which he was so interested aesthetically, ${ }^{22}$ and the Soldier has been pathologized as suffering from post-traumatic stress disorder. ${ }^{23}$ Wordsworth's decision not to voice descriptions of warfare through the Soldier might have been due to his own lack of personal experience of the war zone, a disinclination to introduce harsh realities into the civilian sphere or a sense that what remains undescribed has a more powerful impact on the imagination that that which is directly presented. But what if the question 'why doesn't the Soldier say more about his experiences of war?' were realigned, so that its import is not 'what stops him?' but 'what does his reticence mean?’?

\footnotetext{
${ }^{22}$ See Tilottama Rajan, The Supplement of Reading: Figures of Understanding in Romantic Theory and Practice (Ithaca: Cornell University Press, 1990), p. 145, citing David Sampson, 'Wordsworth and the Poor: The Poetry of Survival', Studies in Romanticism 23.1 (Spring 1984), pp. 31-59 and Robert Langbaum, 'Wordsworth's Lyrical Characterisations', Studies in Romanticism 21.3 (Fall 1982), pp. 319-39. On the social threat posed by discharged soldiers see further Toby R. Benis, Romanticism on the Road: The Marginal Gains of Wordsworth's Homeless (Basingstoke: Macmillan, 2000), p. 198.

23 'The past has been so traumatic that he can no longer even respond to it' (Alan Bewell, Romanticism and Colonial Disease (Baltimore and London: The Johns Hopkins University Press, 1999), p. 119).
} 
An answer to the revised query lies in the image of a hand letting slip an oaken staff-a staff

Which [I suppose] from his slack hand had dropp'd, And such the languor of the weary man, Had lain till now neglected in the grass, But not forgotten. (ll. 117-20)

This is not the only appearance of a staff in Wordsworth's poetry. The Old Cumberland Beggar has a staff, but his is carefully 'placed' across a 'broad smooth stone' (l. 7). The eponym of 'Michael' fashions a 'perfect Shepherd’s Staff' (l. 193) which he gives to his son, figuring his attempt—ultimately unsuccessful—-to bequeath rural traditions to the boy. Another shepherd's staff saves a son's life in Book 8 of The Prelude (8.308-11). In The Prelude, too, Wordsworth and his companion cross the Alps 'staff in hand on foot' (6.341). A staff is a sign of wayfaring, of having come far, of the travelling that is indissociable with storytelling. The Wordsworthian staff intensifies these associations of travel and experience and adds to them connotations of the inter-generational passing-on of wisdom. In the case of the Discharged Soldier, his staff, like his experience, has slipped through his grasp. Another detail from Benjamin's 'The Storyteller' resonates here: that 'what is expressed gains support in a hundred ways from the work-seasoned gestures of the hand' ${ }^{24}$ Hands, that is, collaborate with voice to tell a story. The Discharged Soldier's 'slack hand', which has, elsewhere in the poem, made only meagre, enervated gestures (1l. 87-9, 165-6), is further evidence, alongside his preternaturally still legs and fallen staff, that the ability to do so has atrophied. The poem is a study in the failure of communicable experience, a non-handing on of wisdom.

\footnotetext{
${ }^{24}$ Benjamin, 'The Storyteller', p. 162.
} 


\section{Rebecca West, The Return of the Soldier (1918)}

Let us temporarily leave Wordsworth’s long-legged, lean-handed veteran by the side of the road and leap forward 120 years to Rebecca West's novel, The Return of the Soldier, published in 1918 - a work with a number of Wordsworthian resonances. This work is less well known than the others discussed in this essay, so it is worth briefly summarizing the plot. It is 1916 and Chris Baldry is away fighting in the First World War. His cousin Jenny, who is the novel's narrator, and his wife Kitty remain in the ancestral home, Baldry Court. One day, there is a visitor to Baldry Court, a visitor whose lower-class station Kitty so disdains that she goes down to greet her in 'last year’s fashion’ (23). ${ }^{25}$ The visitor, a Mrs. Margaret Grey, has news of Chris-again this disgusts Kitty, who thinks she is a fraud. It seems that Chris and Margaret had a love affair fifteen years previously in 1901—five years before he got married to Kitty_and he has now written personal letters to her, one of which she produces. Chris now has shell-shock and has lost his memory of everything that has happened since 1901.

Chris returns to Baldry Court. He recognizes his cousin Jenny but not his wife Kitty, and he is desperate to see Margaret. They are reunited and spend idyllic times together. But Kitty wants him to be 'cured'. This is achieved when Margaret reminds Chris of the death of his son Oliver in 1911. The novel ends with Jenny and Kitty watching Chris walk back to the house from the woods where Margaret has reminded him of his son by showing him the child's jersey and ball. He wears 'a dreadful decent smile' and walks 'with the soldier's hard tread upon the heel' (187). Kitty

\footnotetext{
${ }^{25}$ Rebecca West, The Return of the Soldier (London: Virago, 1990). Page numbers are given in the text.
} 
sucks in her breath 'with satisfaction': “"He’s cured!' she whispered slowly. "He’s cured!”' (188).

As is the case with Wordsworth's 'Discharged Soldier', the majority of critical responses to this novel have interpreted the plight of the returned, amnesiac soldier Chris Baldry in psychological or psychoanalytical terms. ${ }^{26}$ Without disputing the insights of these readings, what I want to concentrate on here are the related themes of wisdom and storytelling. Chris has suffered—is suffering—-from a striking temporal reversion. Physically, he bears the signs of age (though not the signs of battle-he has not been physically wounded): on seeing him again, his cousin Jenny, 'crie[s] out' because she notices that his hair is 'of three colours now-brown and gold and silver' (50), and when he takes the boat out on the lake, the effect is disconcerting because it is 'a boy's sport' and it is 'dreadful' to see him 'turn a middle-aged face' as he brings the boat inshore (89). But mentally he is back in 1901, fifteen years younger.

This is, in one of the novel's senses of the phrase, 'the return of the soldier': Chris's return to a time in his past when he was on the cusp of sexual maturity and about to take on adult responsibilities towards the family business from his father. 'Shell-shock' (and rather than inquire further into that term here, I accept it as West offers it (29)) has removed from him the combat experience that could have been expected to have a maturing effect. The fact that he bears no visible war wounds attesting to such experience reinforces the point. But Chris is not so much

\footnotetext{
${ }^{26}$ See, for example, Misha Kavka, 'Men in (Shell-)Shock: Masculinity, Trauma, and Psychoanalysis in Rebecca West's The Return of the Soldier', Studies in Twentieth Century Literature 22 (1998), pp. 15171; Susan Varney, 'Oedipus and the Modernist Aesthetic: Reconceiving the Social in Rebecca West's The Return of the Soldier', Naming the Father: Legacies, Genealogies, and Explorations of Fatherhood in Modern and Contemporary Literature, ed. Eva Paulino Bueno, Terry Caesar and William Hummel (Lanham, MD: Lexington, 2000), pp. 253-75; Wyatt Bonikowski, 'The Return of the Soldier Brings Death Home', Modern Fiction Studies 51.3 (Fall 2005), pp. 513-35; and Steve Pinkerton, 'Trauma and Cure in Rebecca West's The Return of the Soldier', Journal of Modern Literature 32.1 (Fall 2008), pp. 1-12. West is on record as having read William James, Freud, Ernest Jones, Karl Abraham, Sándor Ferenczi, Jung, Adler, Rank, W. H. Rivers and others but protested strongly against psychoanalytical readings of the novel ('On "The Return of the Soldier"', The Yale University Library Gazette 57 (1983), 66-70: p. 68).
} 
rejuvenated as de-aged, de-veteranized, living backwards through time, shedding rather than gaining experience. (This gives fresh illumination to Benjamin's description 'not richer but poorer in communicable experience', going beyond the idea that the war conferred no communicable experience to the suggestion that it actually removed it.)

The true veteran in the novel is Margaret, who has suffered and aged through time. Her name has changed, through marriage, to 'Grey', and in other respects, too, she shows the processes of senescence. Her hat is 'sticky', her boots 'muddy' (it is as though it is she, rather than Chris, who bears the clinging traces of the 'brown rottenness of No Man's Land' (24)). Margaret is associated with redness: the colour of sexual arousal but also a colour produced by work and age. Her house is part of a creeping 'red suburban stain' (22), her hand is 'seamed and red' (24). When Jenny visits her at home, she confesses that she is 'very tired' and 'hot': 'I've been baking' (94). The signs of time, age and work are indelible on Margaret, who, in Jenny's perception, is ‘seamed and scored and ravaged by squalid circumstances' (90). If the nymph-like Kitty is subject to the temporal arrestation of one of Keats' 'marble [...] maidens',27 Margaret is Wordsworth's Margaret, the soldier's wife of 'The Ruined Cottage' (1797-8). The link with Margaret of the 'The Ruined Cottage' is made explicit by the phrase 'red stain': as mentioned, Margaret Grey’s house is situated in a 'red suburban stain', while the door of Wordsworthian Margaret's cottage is 'With dull red stains discoloured' (l. 332). Like Margaret Grey, Wordsworth’s Margaret shows the visible evidence of time and age on her body: 'Her face was pale and thin, her figure too / Was changed' (ll. 338-9). And there is a yet another Wordsworthian

\footnotetext{
${ }^{27}$ John Keats, 'Ode on a Grecian Urn', John Keats: The Major Works, ed. Elizabeth Cook (Oxford: Oxford University Press, 2001), 288-9: p. 289, 1. 42.
} 
resonance. ${ }^{28}$ In Margaret Grey’s two homes-Monkey Island Inn and the suburban house in Wealdstone ${ }^{29}$ — there hangs a picture of a view of Tintern Abbey $(84,93)$. The picture makes the connection to a poem about the process and experience of maturity in which an older and wiser homecomer repudiates 'thoughtless youth' (l. 91). The Wordsworthian intertexts emphasize the accumulation of associations between the character Margaret Grey and experience.

What 'cures' Chris (188)—what reverses the temporal trend and returns him to adulthood (another sense of the 'return of the soldier' which is, in turn, essential to the final 'return of the soldier' to the battlefield) - is the reminder of the death of his son, Oliver. There is a strong sense, indeed, in which the returned Chris has merged with Oliver, who was, with his chivalric / martial name and rocking-horse, a child in warrior-guise. It is as though the reiterated death of the actual child brings about the death of the de-aged Chris. With his 'cure', come the reminder and resumption of his responsibilities: to the family business, to his gender, class and estate; to the childlike Kitty; and, most ominously, to the war. The restored Chris is now 'every inch a soldier' (188). The point is made figuratively by West in terms of gait, a motif that recurs through the novel. Jenny remembers Chris as a young man possessing 'the loveliness of the spry foal' (104), a loveliness that is called to mind when Chris runs over the lawns into the arms of Margaret:

How her near presence had been known by Chris I do not understand, but there he was, running across the lawn as night after night I had seen him in my dreams running across No Man’s Land. (122)

\footnotetext{
${ }^{28}$ Nicole Rizzuto also draws attention to this allusion ('Towards an Ethics of Witnessing: Traumatic Testimony in Rebecca West's The Return of the Soldier', College Literature 39.4 (Fall 2012), 7-33: pp. 21-4).

29 'Wealdstone' also carries veteran connotations in the homophone 'wield stone' and the sound 'weal'. The former sounds like an act of combat, the latter is the mark left by a lash. In contrast, 'Monkey Island' might denote a venue for youthful japes.
} 
If Chris is not 'cured', Jenny reflects, instead of running lithely he will 'walk for ever queer and small like a dwarf' (182). But when the 'cure' has been effected, Chris walks 'not loose limbed like a boy, as he had done that very afternoon, but with the soldier's hard tread upon the heel' (188). The soldier has marched back, banishing the boy.

As critics have noted, the returned amnesiac veteran creates narratological quirks and articulates an understanding of trauma as a revenant phenomenon. ${ }^{30}$ But here I would like to make another suggestion: that the de-veteranizing of Chris figures the removal of his capacity for storytelling. This is, after all, a character who has just returned from two years of fighting in the First World War. Yet the only person who offers any description of the war-indeed, of Chris's past at all-is Jenny. The First World War appears in the novel solely through her dreams and imaginings. ${ }^{31}$ Jenny, like Margaret, has aged through time, becoming a quasi-veteran. 'Jenny the woman' is explicitly separated from 'Jenny the girl', and, on Chris's return, she feels 'shame’ that she is 'thirty-five instead of twenty' $(61-2,50)$. But Jenny's knowledge of the First World War has been gleaned from 'war-films' (13-14). Her vision of it is consequently artificial, composed of and conveyed by a few standard, even clichéd, images: 'barbed-wire entanglements', 'booming noise', 'splashes of fire', 'wails for water' and the 'brown rottenness of No Man's Land' $(86,13,24)$. Jenny's is an attenuated, derivative version of First World War veterancy, and the representation of the conflict projected through her is similarly derivative. It is eminently possible to read this situation as symptomatic of the problems of witnessing, including the right

\footnotetext{
${ }^{30}$ See, for example, Steve Pinkerton, 'Trauma and Cure in Rebecca West's the Return of the Soldier', Journal of Modern Literature 32.1 (Fall 2008), pp. 1-12.

${ }^{31} \mathrm{Cf}$. 'Like a traumatized soldier, Jenny is plagued by nightmares of war' (Bonikowski, 'The Return of the Soldier Brings Death Home', p. 522).
} 
to bear witness for those who witness. ${ }^{32}$ But, again, I would propose a reading with an epistemological framework.

The classic homecoming veteran scenario is the recognition scene, involving the soldier returned so altered by experience that he is initially unrecognisable. This is what happens in the Odyssey. In The Return of the Soldier, the scenario is varied: Chris is initially physically recognisable but there is a psychological dissonance-his wife and cousin cannot recognize his mental state. When he is returned to his 1916 self, he also comes to recognition himself: of his marriage, house, history and responsibilities. None of these are unproblematic. Terence Cave notes that classic Aristotelian recognition (anagnorisis) 'brings about a shift in ignorance to knowledge'. ${ }^{33}$ From this premise, Cave traces the diffusion of the family recognition scene into plots concerning the recovery of knowledge. West's anagnorises are more troubling. The initial recognition of the homecomer is imperfect-he is not what he seems - and the final recovery of knowledge is disquieting: it is knowledge that will send a man back to the field of slaughter. The recuperation and passing-on of knowledge have been vitiated, the past devalued.

The implications for storytelling are given figurative expression in Jenny's dream of wounded veterans:

'We were all of us in a barn one night, and a shell came along. My pal sang out, “Help me, old man, I've got no legs!” and I had to answer, “I can't, old man, I've got no hands!"' (14)

\footnotetext{
32 See Margaret Higonnet, 'Authenticity and Art in Trauma Narratives of World War I', Modernism/Modernity 9.1 (January 2002), pp. 91-107; Trudi Tate, Modernism, History and the First World War (Manchester: Manchester University Press, 1998), p. 19; and Rizzuto, 'Towards an Ethics of Witnessing', p. 8.

${ }^{33}$ Terence Cave, Recognitions: A Study in Poetics (Oxford: The Clarendon Press, 1988), pp. 1, 28.
} 
The significance of hands in the novel has already received critical attention, ${ }^{34}$ but here I would again recall Benjamin's remark in 'The Storyteller' that 'what is expressed gains support in a hundred ways from the work-seasoned gestures of the hand'. Without hands, the second veteran of Jenny's dream is impaired in his ability to hand on stories, while his comrade, lacking legs, is precluded from the wayfaring upon which storytelling also depends. Here again, then, is the storyteller produced by modern mass warfare: the effectively de-veteranized veteran, legless and handless, unable to pass on the benefit of experience. In Virginia Woolf's Mrs Dalloway, this figure reappears in extremis.

\section{Virginia Woolf, Mrs Dalloway (1925)}

Our third literary veteran is probably the most famous and most discussed First World War veteran in modernist literature-Virginia Woolf's Septimus Warren Smith, from her 1925 novel, Mrs Dalloway. Like Wordsworth’s and West's veterans, Septimus has been extensively explored from psychological and psychoanalytical standpoints $^{35}$ and, again, I realign the discussion to query, not the cause, but the meaning of his silence. For Septimus, 'the eternal sufferer' (22), ${ }^{36}$ is a veteran who is completely unable to speak from experience. There is evidence that, earlier in the war, he could communicate with his sergeant, Evans: they 'share', 'fight', 'quarrel' and 'growl good-temperedly' at each other (73). He could also communicate with his

\footnotetext{
${ }^{34}$ See Marina Mackay, 'The Lunacy of Men, The Idiocy of Women: Woolf, West, and War', NWSA Journal 15.3 (Autumn 2003), 124-44: pp. 133-4.

${ }^{35}$ See, for example, Sue Thomas, 'Virginia Woolf's Septimus Smith and Contemporary Perceptions of Shell Shock', English Language Notes 25.2 (1987), pp. 49-57; Elizabeth Abel, Virginia Woolf and the Fictions of Psychoanalysis (Chicago: University of Chicago Press, 1989); Karen deMeester, 'Trauma and Recovery in Virginia Woolf's Mrs Dalloway', Modern Fiction Studies 44.3 (1998), pp. 649-73; Karen Levenback, Virginia Woolf and the Great War (Syracuse: Syracuse University Press, 1999); and Roberta Rubenstein, “I Meant Nothing by the Lighthouse': Virginia Woolf's Poetics of Negation', Journal of Modern Literature 31.4 (Summer 2008), pp. 36-53.

${ }^{36}$ Virginia Woolf, Mrs Dalloway, ed. David Bradshaw (Oxford: Oxford University Press, 2000, 2009). Page numbers are given in the text.
} 
wife-to-be Lucrezia: '[a]nything, anything in the whole world [...] she would tell him, and he understood at once' (124). But now, in 1924, he talks only to himself and to the dead, uttering 'hard, cruel, wicked things' (55). In a grotesque version of Benjamin's companionable storyteller, he is intensely conscious of the importance of passing on acquired knowledge, but the knowledge is fantastical, the interlocutors equally so:

$[\mathrm{H}] \mathrm{e}$, Septimus, was alone, called forth in advance of the mass of men to hear the truth, to learn the meaning, which now at last, after all the toils of civilization-Greeks, Romans, Shakespeare, Darwin, and now himself—was to be given whole to. . . . 'To whom?' he asked aloud. 'To the Prime Minister,' the voices which rustled above his head replied. The supreme secret must be told to the Cabinet; first that trees are alive; next there is no crime; next love, universal love, he muttered, gasping, trembling, painfully drawing out these profound truths which needed, so deep were they, so difficult, an immense effort to speak out. (57)

The 'profound truths' are chimeras; they are, even so, not fluently exchanged but 'painfully draw[n] out' by 'immense effort'. Moments later, 'hard, white, imperishable words' fall 'like shells' from Septimus's mouth, but these turn out to be not pearls of wisdom for mutually edifiying circulation but inscrutable phenomena that fly 'to attach themselves to their places in [...] an immortal ode to Time' (59). As the words uselessly, uncontrollably fall and fly, Septimus sees his dead comrade, Evans, walking towards him, but there is something extraordinary about him: 'A man in grey was actually walking towards them. It was Evans! But no mud was on him; no wounds; he was not changed' (59). Here, again, in this vision is the de-veteranised 
veteran: the reversal of the war's effects on his body figures the absence of knowledge gained from experience.

As isolated from communicative exchange is Septimus's wife Rezia, cut off from her Italian family, determined to conceal the 'failure' of his eccentric behaviour, unable to tell anyone, 'not even Septimus', that he is 'not Septimus now' $(13,20)$. There are moments when Rezia’s desperation almost forces her to cry out for help to strangers, 'to butchers' boys and women'; yet at the same, she fears that '[p]eople must notice; people must see’ $(20,13)$. Her terror makes Rezia adept in directing and re-directing people’s attention away from Septimus's comportment and from her own suffering. And she directs Septimus's attention, too, in attempts to distract him from his visions and so normalize his behaviour; this is on medical advice from Dr. Holmes who has 'told her to make her husband (who had nothing whatever seriously the matter with him but was a little out of sorts) take an interest in things outside himself' (18). Rezia is constantly bidding Septimus to 'look’ (18, 20-1): instead of engaging in discursive interaction, the couple is reduced to physical deictics and glances at scenes and objects. But rather than participate even in this limited shared perception, Septimus closes his eyes: 'he would see no more' (19). In an exemplary moment, Rezia spreads her hand in front of them both: 'Look! Her wedding ring slipped—she had grown so thin. It was she who suffered—but she had nobody to tell' (20). His reaction-separated from her action by some forty pages and so emphasising the discursive and emotional disconnect between them—-baffles her:

What then had happened — why had he gone, then, why, when she sat by him, did he start, frown at her, move away, and point at her hand, take her hand, look at it terrified? (57)

Septimus, for his part, has misinterpreted the gesture: 
He dropped her hand. Their marriage was over, he thought, with agony, with relief. The rope was cut; he mounted; he was free [...] (since his wife had thrown away her wedding ring; since she had left him). (57)

The incident epitomises the complete communicative failure between the two. What is notable for present purposes is that this is, again, figured by a hand. We have already twice noted Benjamin’s remark that 'what is expressed gains support in a hundred ways from the work-seasoned gestures of the hand'. The gesture made by Rezia's hand not only fails to support what she is expressing but produces an unintended meaning. Note, too, that this is the hand of someone who has grown thin through suffering (there are resonances here again with Wordsworth's 'pale and thin' Margaret of 'The Ruined Cottage'). Rezia herself shows the physical evidence of veterancy, but, like her war veteran husband, she has no wisdom to impart.

'In most narrative fiction and drama until modern times,' writes Cave, 'anagnorisis has been total, in the sense that it reveals all that the characters want or need to know; the desire for knowledge is ostensibly set to rest. ${ }^{37}$ But modernist anagnorises have included a 'sub-category of imperfect recognitions' or instances, like that in Waiting for Godot, 'in which an expected recognition wholly fails to materialize'. ${ }^{38}$ The failure of recognition makes the point that knowledge is being neither recovered nor handed on. Mrs Dalloway demonstrates as much in a catalogue of non-communication and misunderstood gestures, spreading from the desperate attempts at inter-change by Septimus and Rezia to the community at large. Even in what should be a forum for companionable storytelling—Mrs Dalloway's party-the news of Septimus's death, offered by Lady Bradshaw as a social excuse, functions

\footnotetext{
${ }^{37}$ Ibid., 233.

${ }^{38}$ Ibid., 233.
} 
only to make Clarissa think of the self-serving nature of communal interaction, and its easy foundering.

\section{Modernity's Unknowing}

In each of the three texts, a returning war veteran-injured, traumatized, unable properly to articulate what has happened-figures a radical undermining of the possibility of profiting from experience. Unknowing, each is also unknowable. The knowledge that is absent is not only the content of conscious recall but also emotional and somatic understanding. ${ }^{39}$ But Wordsworth's Soldier discharged from the French Revolutionary Wars suggests that the crisis in communicable experience that Benjamin tied to the First World War has a longer history. In fact, Benjamin's 'vagueness in providing a chronology' for the decline of Erfahrung has been noted by critics, ${ }^{40}$ and many of the factors to which he attributed it came into being with the Industrial Revolution. His horror at the First World War was due, in part, to the devastating impact of the weapons technology it drew on; ${ }^{41}$ the French Revolutionary Wars, too, were notable for their physical attrition, ${ }^{42}$ as well as being huge in

\footnotetext{
${ }^{39}$ The Discharged Soldier is, as noted, described as 'Remembering the importance of his theme / But feeling it no longer (ll. 139-44)'. Chris Baldry has no haptic or motor memories of the war like those which cause him to fall down recently installed stairs at his home. In Mrs Dalloway, the reader is told six times that Septimus 'could not feel' $(74,75)$. My emphases.

${ }^{40}$ Jay, Songs of Experience, p. 343.

${ }^{41}$ In an essay of 1925, 'Weapons of Tomorrow', Benjamin wrote starkly of the horrors of chemical warfare, describing the toxic gases which played a part in the war as a 'truly breathtaking hazard' ('[E]in wahrhaft atemraubender Hasard’ (Walter Benjamin, 'Die Waffen von Morgen: Schlachten mit Chlorazetophenol, Diphenylaminchlorasin und Dichloräthylsulfid', Gesammelte Schriften, IV.1,2.4736: p. 473 (my translation)).). 'Imperialist war', he said later in 'The Work of Art in the Age of Mechanical Reproduction' (1935-6), 'is an uprising on the part of technology', which 'demands repayment' in "'human material”' for the "“natural material”" that society has denied it ('The Work of Art in the Age of Its Technological Reproducibility' (Second Version), Selected Writings. Volume 3: 1935-38, trans. Edmund Jephcott and Harry Zohn, 101-33: pp. 121-22).

${ }^{42}$ In the French Revolutionary and Napoleonic Wars, soldiers were facing mortars, furnace bombs, grapeshot and canister shots as well as muskets, pistols, swords, bayonets and pikes (see Terence Wise, Artillery Equipments of the Napoleonic Wars (Oxford: Osprey Publishing, 1979)). In the Napoleonic Wars alone around a million men died 'from battle wounds' - in Britain, a greater proportion of the population died than in the First World War-and that figure ignores other fatalities and casualties (Robert L. O'Connell, Of Arms and Men: A History of War, Weapons, and Aggression (Oxford: Oxford University Press, 1989), p. 185). Death became routine: O’Connell notes a 'lemminglike
} 
geographical reach and extended over time. (They lasted ten years, reached from Europe to the Middle East to the Caribbean and involved fighting in the Mediterranean Sea and Atlantic and Indian Oceans.) Anders Engberg-Pederson has recently drawn attention to the epistemological impact of these wars, noting that their 'magnitude and character' gave rise to 'a conception of war as a world unto itself in which the usual understanding time, space, and knowledge [was] profoundly reconfigured': ${ }^{43}$

On the battlefield epistemic conditions came to be regarded not only as inherently deficient; the fundamental state of knowledge was seen as contingent. [...] war emerges as a realm of radical contingency, a realm shot through with chance events, replete with errors and uncertainties. ${ }^{44}$

'Faced with a probabilistic complexity that neither Euler nor Newton would be able to handle', Engberg-Pedersen writes, the commander in the French Revolutionary Wars was obliged to resort to 'the subconscious operations of the mind in order to perform the probability calculus' ${ }^{45}$ Military success, tactical and strategic, was a matter of taking an educated guess, in other words, and it might seem that in such conditions Erfahrung would flourish. Indeed, Engberg-Pedersen makes a plausible case for the value of experience for both the individual fighter and the high command. But achieving military success is not the same as making sense of what one has been through. The 'new epistemic order' which Engberg-Pedersen describes turns battle into a form of gambling on an extended scale, repeated life-or-death encounters with

quality' in the soldiers of these times that foreshadowed the 'mass acceptance of death so characteristic of the great industrial wars of the twentieth century' (ibid., p. 185).

43 Anders Engberg-Pedersen, Empire of Chance: The Napoleonic Wars and the Disorder of Things (Cambridge, MA: Harvard University Press, 2015). p. 38. Engberg-Pedersen's argument applies to both the French Revolutionary and the Napoleonic Wars, but I am concentrating on the former as the theatre of war in which Wordsworth's Discharged Soldier would have been involved.

${ }^{44}$ Engberg-Pedersen, Empire of Chance, p. 4.

${ }^{45}$ Ibid., p. 78. 
chance. ${ }^{46}$ The French Revolutionary Wars, in his words, marked 'a caesura in history, both from a military and an epistemological point of view' ${ }^{47}$ Fighting in those wars was not the same as fighting in the First World War, but the two had this unprecedented element in common: the experience of the individual soldier was a state of radical and terrifying uncertainty.

As a result both wars defied assimilation and transmission as traditional wisdom. And this is what Wordsworth, Woolf and West's literary imaginations seized upon, taking the veteran of modern, mass, industrialized warfare as a prime exemplar of the person who cannot make sense of his experiences and who cannot, therefore, be made sense of by others. But in deploying this figure, the three writers, I suggest, were saying more than the obvious '(this) war is senseless'. My argument is that they created characters who are at odds with modernity-modernity here understood (and this is just one of the meanings explored in this volume as a whole) in broad terms as synonymous with the project of the Enlightenment, ${ }^{48}$ which was to eradicate myth and substitute for it rational scientific method.

This argument takes as its starting-point the classic work of Theodor Adorno and Max Horkheimer, Dialectic of Enlightenment (1944). In this account, 'myth is already enlightenment' and 'enlightenment reverts to mythology' ${ }^{49}$ Myth itself arose from early attempts to make sense of the world (this kind of explanatory myth resembles Erfahrung). The 'program of the Enlightenment' was 'the disenchantment of the world': the 'dissolution of myths and the substitution of knowledge for

\footnotetext{
${ }^{46}$ Ibid., p. 68.

${ }^{47}$ Ibid., p. 51.

${ }^{48}$ I follow Robert Pippin in using 'modernity' and 'the Enlightenment' 'interchangeably' (Modernism as a Philosophical Problem: On the Dissatisfactions of European High Culture (Oxford: Blackwell, 1991), p. 4). I use 'enlightenment' to refer to the scientific approach and 'Enlightenment' to refer to the historical intellectual movement.

${ }^{49}$ Adorno and Horkheimer, Dialectic of Enlightenment, p. xvi.
} 
fancy'. ${ }^{50}$ But enlightenment has something in common with myth: it, too, attempts to make sense of the world. 'Making sense of' is a form of mastery, and it becomes allconsuming. The 'dutiful child of modern civilization' is 'possessed by a fear of departing from the very act of perception' which 'the dominant conventions of science, commerce and politics' have 'already molded'. ${ }^{51}$ Demanding total allegiance to its method and its findings, enlightenment is eventually 'totalitarian'. ${ }^{52}$ This is, in many ways, a problematic view of the Enlightenment which risks obscuring its very real and multitudinous technological and civic achievements-a point which Adorno and Horkheimer accepted and which another philosopher also associated with the Frankfurt School, Jürgen Habermas, insisted upon. ${ }^{53}$ But this acknowledgement can co-exist with the view that 'enlightenment brings new and seemingly irreversible forms of domination', a view shared by, among others, Martin Heidegger and Georges Bataille. ${ }^{54}$ As it happens, Adorno and Horkheimer use a homecoming veteran-Odysseus - to illustrate their thesis. They quote from the French historian Gustave Glotz's description of Odysseus in Ithaca to characterize the state of enlightenment:

[A 'proprietor like Odysseus'] manages from a distance a numerous, carefully gradated staff of cowherds, shepherds, swineherds and servants. In the evening, when he has seen from his castle that the countryside is illumined by a thousand fires, he can compose himself for sleep with a quiet mind: he

\footnotetext{
${ }^{50}$ Ibid., p. 3.

${ }^{51}$ Ibid., p. xiv.

52 Ibid., p. 6.

53 'We have no doubt [...] that freedom in society is inseparable from enlightenment thinking' (Adorno and Horkheimer, Dialectic of Enlightenment, p. xvi). Habermas, whose career has been devoted to understanding the mechanisms of rational communication, particularly noted 'the universalistic foundations of law' produced by Enlightenment modernity. He described Dialectic of Enlightenment as Adorno and Horkheimer's 'blackest book' (The Philosophical Discourse of Modernity: Twelve Lectures, trans. Frederick G. Lawrence (Cambridge, MA: The MIT Press, 1985), pp. 113, 106).

${ }^{54}$ See Rebecca Comay, 'Gifts without Presents: Economies of Experience in Bataille and Heidegger', Yale French Studies 78 (1995), pp. 66-89: p. 69.
} 
knows that his upright servants are keeping watch lest wild animals approach, and to chase thieves from the preserves which they are there to protect. ${ }^{55}$

In Adorno and Horkheimer's allegorical reading, Odysseus' adventures during his return from war become the scientific advances of the Enlightenment, culminating in a state in which, back home in Ithaca and in full control of his estates and servants, he can sleep easily. ${ }^{56}$ The contrast between the 'quiet mind' of this returned veteran and the troubled psyches of the Discharged Soldier, Chris Baldry and Septimus Warren Smith is striking. Where do they fit in this account of the progress of modernity?

They obstruct it. In some small way, these figures of unknowing resist the relentless onward surge of enlightenment. Not being able to make sense of something is, after all, the opposite tendency to that of knowing and mastering the world. And, as Adorno and Horkheimer note, while '[e]loquent discourse' is 'the law of Homeric escape ${ }^{, 57}$ - that is, the language of scientific method_- '[r]eticence in narrative' is the means by which 'the semblance of freedom glimmers'. ${ }^{58}$ Seen in this light, the noncommunication of the Discharged Soldier, Chris Baldry and Septimus Warren Smith is a refusal to acquiesce in the domination of enlightenment.

'Refusal' might be too optimistic a word: there is no sense that any of the three have any choice in their unknowing. Nor is their condition presented as enviable. There is no Lotos-Eater-like willingness or even desire to remain in ignorance here. The three veterans are consistently met with consternation. And, in

\footnotetext{
55 Quoted from Gustave Glotz, Histoire Grecque, vol. 1 of Histoire Ancienne (Paris: Presses Universitaires de France, 1938), p. 140 (Adorno and Horkheimer, Dialectic of Enlightenment, p. 14).

${ }^{56}$ Philip Weinstein endorses the analogy: "Returning to Ithaca": what is that but the return to an enlarged self-knowledge- the progressive story of Western reason and imagination finding themselves fulfilled in time, from Descartes to Kant and the Romantics and beyond?' (Unknowing, p. 19). Neither Adorno and Horkheimer nor Weinstein deal with the point that, having asserted full mastery over his kingdom, Odysseus only stays there a night: presumably Adorno and Horkheimer would say that the dialectical process begins again.

${ }^{57}$ Adorno and Horkheimer, Dialectic of Enlightenment, p. 78.

${ }^{58}$ Ibid., p. 79.
} 
consequence, a certain unease is transferred to the circumstances of their creation, for what is the writing of poetry and fiction if not an act of imaginative understanding, on the part of both author and reader? Stupefaction marks the death of the empathy on which writing creatively depends. This, then, is how the story ends-in an exhausted man propped by the roadside on a moonlit night, an infantilized amnesiac and a hallucinatory suicide. 